International Research Journal of Management, IT \& Social Sciences
Available online at https://sloap.org/journals/index.php/irjmis/
Vol. 7 No. 1, January 2020, pages: 138-144
ISSN: 2395-7492
https://doi.org/10.21744/irjmis.v7n1.832

\title{
The Motivation and its Importance in the Teaching-Learning Process
}

CrossMark

Carmen Magdalena Mero Alcivar ${ }^{\text {a }}$

Tatiana Lizeth Ibarra Quimi ${ }^{\text {b }}$

María Fernanda Zambrano Barberan ${ }^{\mathrm{c}}$

Article history:

Submitted: 09 November 2019

Revised: 18 December 2019

Accepted: 07 January 2020

\section{Keywords:}

importance;

knowledge;

learning;

motivation;

strategy;

\section{Corresponding author:}

Carmen Magdalena Mero Alcivar,

Unidad Educativa “Jama”, Manabi, Ecuador.

Email address: carmitam63@gmail.com

\begin{abstract}
This article aims to analyze the motivation and importance in the teachinglearning process for students and the teacher and how the interrelation of meaningful learning between the teacher who imparts knowledge-generating stimulate their classes and students who are capable to explore, investigate, learn new skills through the motivation provided by the educational setting. The qualitative research describes theoretical content, guided by the deductiveinductive method referenced from journals, bibliographies, and analyticaldescriptive. It has, as a result, the motivation in students, techniques and methodological strategies to achieve their goals.
\end{abstract}

International research journal of management, IT and social sciences (C) 2020. This is an open access article under the CC BY-NC-ND license (https://creativecommons.org/licenses/by-nc-nd/4.0/).

\footnotetext{
a Unidad Educativa "Jama", Manabi, Ecuador

b Unidad Educativa del XXI "Anchundia Andrade Génesis", Portoviejo, Manabí, Ecuador

" Unidad Educativa "San Cayetano", Chone, Manabí, Ecuador
} 


\section{Introduction}

At present, the educational environment is changing. In different institutions, they are taking a turn around the new models of educational centers that are being updated every year to improve the teaching-learning process for students so that they are professionals capable of undertaking for life, teachers as a primary element, are facilitators of new study strategies and motivate showing interest to students, the importance of developing skills, aspirations, interests and ideals in education.

Motivation is an internal part of the behavior of the human being also maintains complex emotional processes that determine the activity of man, against society. According to Rodríguez (2012), understand the different emotions of man, and being motivated drives him to raise his self-esteem, the ability he has to highlight his previous and acquired knowledge.

There is a cycle of motivation for the different aptitudes and attitudes of each person in their intellectual capacity that they develop, for this reason, the objective of this research is about the importance of motivation in learning, a topic that arouses interest in the role that a teacher plays in motivating and encouraging their students to strengthen integral development.

Within the investigation the motivation has as particular to show the intellectual and personal capacity in the students, depending on the stimulation, the importance of the motivation in the teaching in the students is necessary, since it allows opportunities to the success or also to leave the failure, be this emotional or student, in compliance with the research, it is increased in an educational way and with profit the use of motivating techniques so that the student generates values and demands in their knowledge, on the other hand, the teachers must provide greater motivation in the students within and outside the context of learning giving productivity the educational environment.

\section{Materials and Methods}

This article implemented qualitative research because the theoretical peculiarities of motivation and the teachinglearning process were described; In addition, the research is bibliographic, evidenced in the development of the work, based on an extensive bibliographic search in books, internet magazines and other materials that were analyzed. Deductive-inductive and analytical-descriptive methods were used.

The bibliographic, because thematic contents are supported by citations extracted from texts and electronic sections that served as references that demonstrate the research perspective; deductive is used to describe the themes that started from the general to the particular; inductive because contents of facts that started from the particular to the general were analyzed; Analytical-descriptive, because a detailed narration of various contents was made with critical contributions and relevant purposes to explain reality.

\section{Results and Discussions}

It is an internal force of each human being, for (Ospina, 2006), the stimulation defines it as an internal connection that energizes and directs a behavior in a positive, creative way for the student, in the same way, he mentally activates his knowledge that he expresses from his own being to create a good learning; Also, it awakens the logical part of their attitudes to learning more each day for their daily lives.

\section{The motivation}

Also (Cazorla, 2015), it states that motivation is a process that promotes self-interest with two fundamental internal and external factors that obtain significant benefit in learning with students in behavior so as to create habit, store new things and sustain a productive activity in every effort made since this satisfies your motivation in a positive or negative way.

Currently, students are motivated by teaching strategies, which is what I mentioned (Revelo, 2018), which is used with high school students in practical activities, the collaborative learning technique (TAC), they develop the exchange of knowledge skills, motivation is generated in groups, obtaining positive results in an evaluation.

Alcivar, C. M. M., Quimi, T. L. I., \& Barberan, M. F. Z. (2020). The motivation and its importance in the teachinglearning process. International Research Journal of Management, IT and Social Sciences, 7(1), 138-144. 


\section{Types of motivation}

The types of motivation in learning according to (E. Llanga, 2019), comments that there are different people who have goals and objectives that exist, the extrinsic motivation that refers to not always going to be motivated to carry out some activity, sometimes interest is diminished, that is, you need another person to encourage you to continue, on the other hand, the intrinsic motivation, this is to make agility for pleasure and allows you to do activities and be an autonomous and competent person; the positive motivation is the one that is always with the desire for gratification is driven by itself, the negative motivation is born from the failure of the person who appears if they do not reach their achievement; The basic motivation is the one that focuses on commitment, the daily motivation is the one that is presented and short-term goals are met. Figure 1 shows the types of motivation in learning.

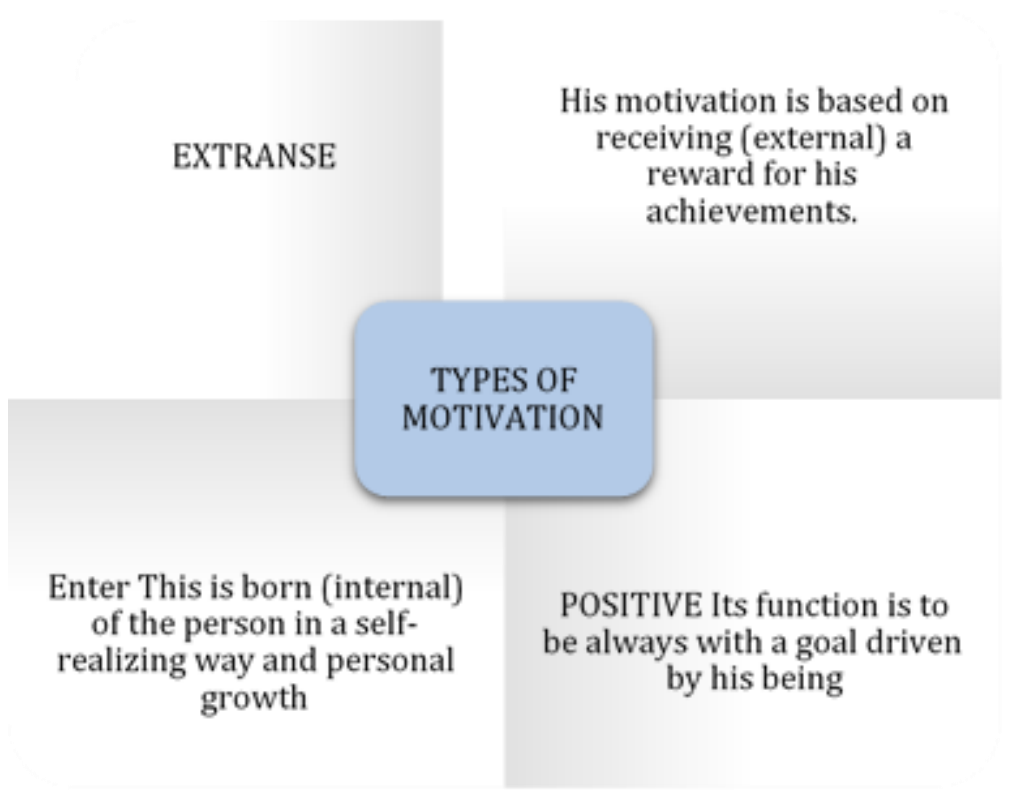

Figure 1. Types of motivation

The types of motivation used in learning with more frequencies are; intrinsic motivation and extrinsic motivation, which depends on them being in functions of being positive or negative when motivating. You should always motivate with interests when teaching activities that develop progress in the attitude of the human being.

Also, Morón (2011), states that intrinsic motivation is necessary for people, as well as for teachers and students because three experiences are born:

a) Improve what you have learned and the desire to compete with your own knowledge.

b) Performing activities for his own interest elevates his emotional ego and rewards himself for the proposed goal.

c) Nature is part of your motivation, makes you get out of the routine and changes the way you develop the skills you propose

\section{Motivation cycle}

The cycle that maintains motivation is necessary, and I consider that they help the human being in aspects such as; The balance of measuring their self-esteem is their own ego that sometimes it is inevitable to express it towards others, the stimulus / or incentive is what drives to continue with the proposed goal, the need is to be well with himself and other people showing the effort, the Tension is the insecurity that you feel even when you receive motivation, this behavior reflects the humility and values that you provide while obtaining a goal, and finally satisfaction, is to be persevering, constant in the face of any adversity. In figure 2 , the motorcycle is observed. 


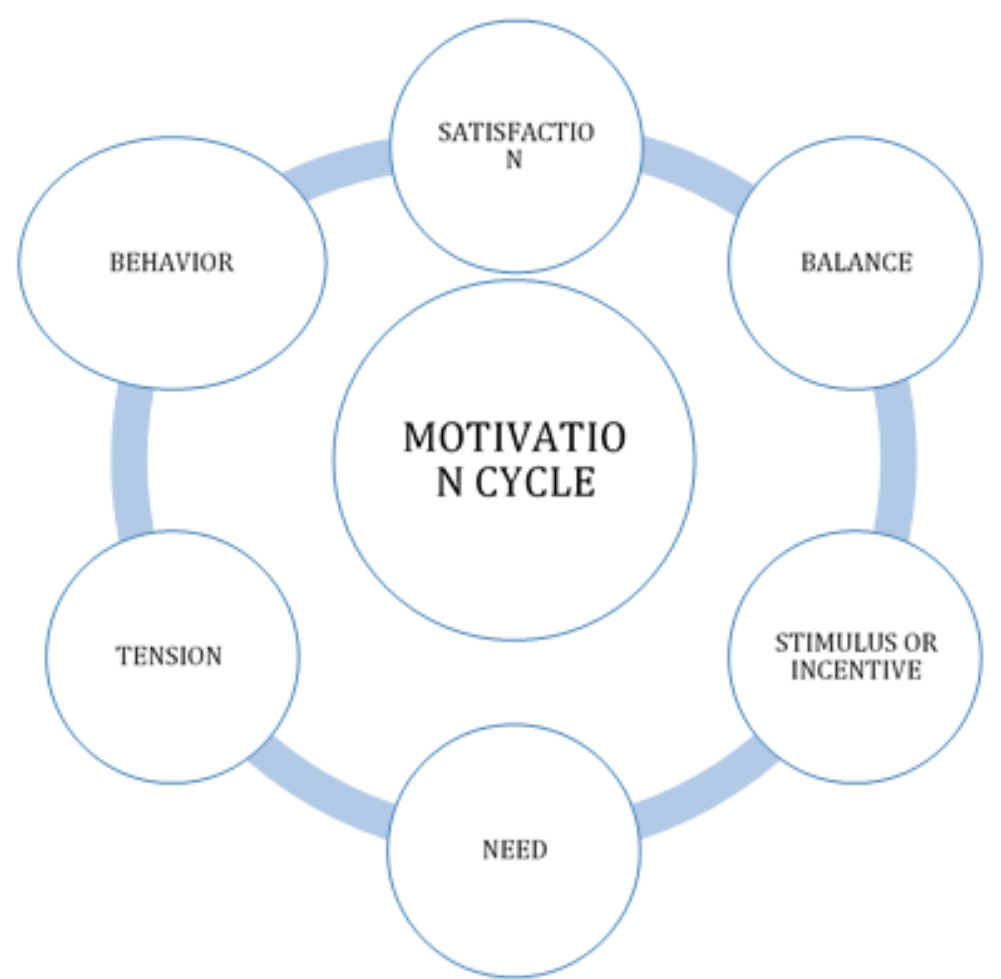

Figure 2. Motivation cycle

\section{Motivation and learning}

For García (1997), learning and motivation have three necessary elements within an institution; the teacher, the content and the students. Because the teacher has a large part of the cognitive field in learning, students are emotionally motivated in teacher's occasions to obtain learning goals, focused skills, knowledge and emotions.

The motivation in learning also explains it (Cazorla, 2015), as the basis for starting from previous experiences or knowledge, oriented in an academic way, to treat the processes that develop skills, abilities, maturity, logic and their sensitive part, these processes they are complex factors such as biological, personal, social, but that if they allow to cope with any situation.

Motivation must go hand in hand with education and the teaching-learning process, it is essential that the teacher be the one that drives students to be dependent on actions, and responsible for tomorrow's future. With another criterion, it indicates (Sotomayor, 2016), that in recent years the use of (ICT) has been incorporated as an educational technology tool to motivate students of higher levels, that is, first, the second and third year of high school.

The teacher according to their area of study is not relevant in some students the implementation of ICT, due to misuse of information that is generated improperly when used outside the educational institution, on the other hand, in students who receive related topics in the subjects of technical areas, if it is favorable and necessary because it allows motivating the student to be explanatory and relate the acquired learning, within the educational context. In figure 3 , motivation and learning are analyzed.

Alcivar, C. M. M., Quimi, T. L. I., \& Barberan, M. F. Z. (2020). The motivation and its importance in the teachinglearning process. International Research Journal of Management, IT and Social Sciences, 7(1), 138-144. 


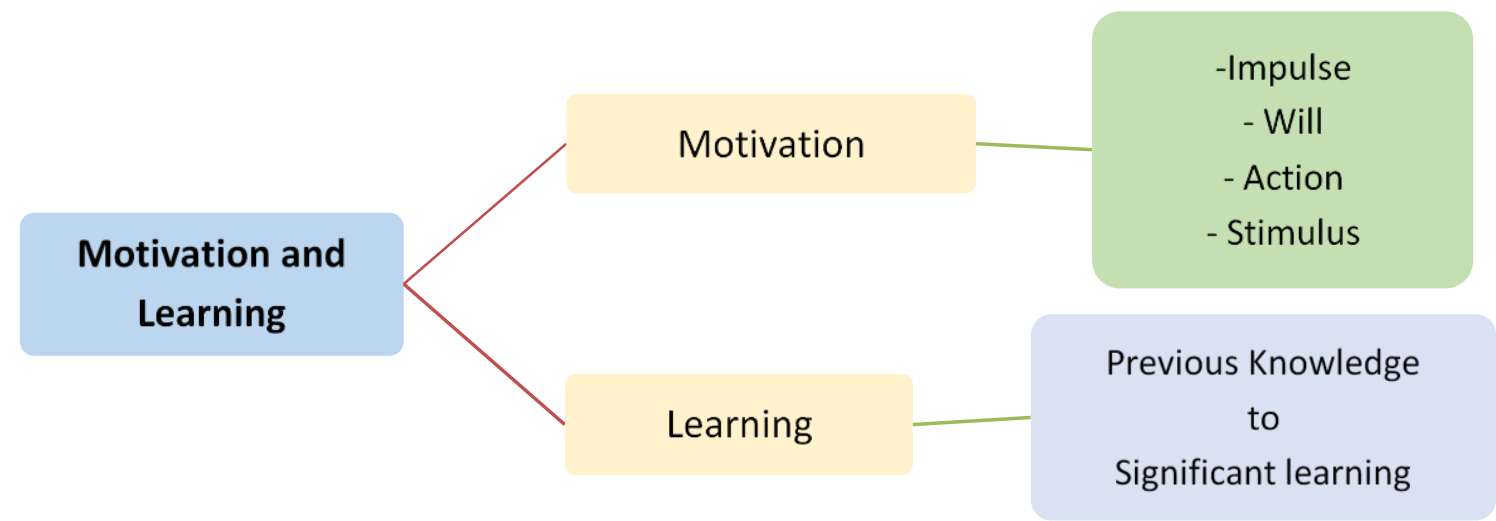

Figure 3. Motivation and learning

\section{Importance of motivation}

The importance of motivation (Ospina, 2006), mentions that the teacher is a character that plays an important role in establishing a relationship of trust to motivate in the construction of knowledge and learning, for example, be on the lookout to guide in the methodological, didactic processes, awakening the level of development that they can expose.

The brain causes the human being to generate a behavior of changes in behavior (Mero, 2019), explains that the brain creates brain processes that start from previous knowledge, therefore it receives a motivational stimulus through external information, which indirectly causes him to produce an involuntary self-esteem when developing some skill in his learning is an elementary part of life.

At present it is sometimes difficult to apply motivational theories in the classroom since they are forgotten by those involved in education; (Valenzuela, 2015: Macías et al., 2018), affirms that school learning has its own knowledge and that it depends on subjects such as (mathematics, science, etc.) to be motivated within the context.

\section{Learning}

In learning, experiences that flow within the classroom regarding motivation with emotional self-regulation is considered (Moreno \& Rodriguez, 2018; Alava \& Martinez, 2019), so that emotions are spontaneous as well as the ability to improve intrinsic motivation in the student, the teacher is incorporated in leveling the methodological proposals to improve enrichment for meaningful learning.

At the world level, the famous digital era has been formed that students are updated more and more every day, that students do not motivate them if they do not perform with some kind of technology or technological programs then (Maggiolini, 2013), in their research analyzes that One way to motivate the aulic classes requires that digital tools such as (mobile phones, laptop, or programs as an instrument or work material)

In the new digital era, the paradigms take a turn of change to conceive meaningful learning, for therefore (B. Álvarez) where the processes do not limit the teacher that the students activate basic cognitive processes and conservation of information for new learning situations, the teacher being a mediator of motivation for the student.

A teacher who has knowledge about motivation and learning must have various theories of motivation, is to increase their research and application of it to students to improve or highlight the learning they acquire during the educational process that increases attention and Interest in his career. According to Alemán et al. (2018), when investigating the teachers of the different motivational theories, it does not imply precisely to nurture the cases but to sustain the academic rhythm of an institution in learning.

Currently the increased reality as an educational tool: application to pre-school, primary, secondary and high school education, as learning is developed with technology in several countries, the progress is satisfactory that students are motivated and in love with the theme they receive with new tools (Web 2.0, the semantic web, 3D printers, MOOCs 
up to $360^{\circ}$ videos.) of practical experimental training work, so that the teacher's connection with the learners is motivating, that way they can cope with society in an updated way in learning. The elements of learning are described in figure 4.

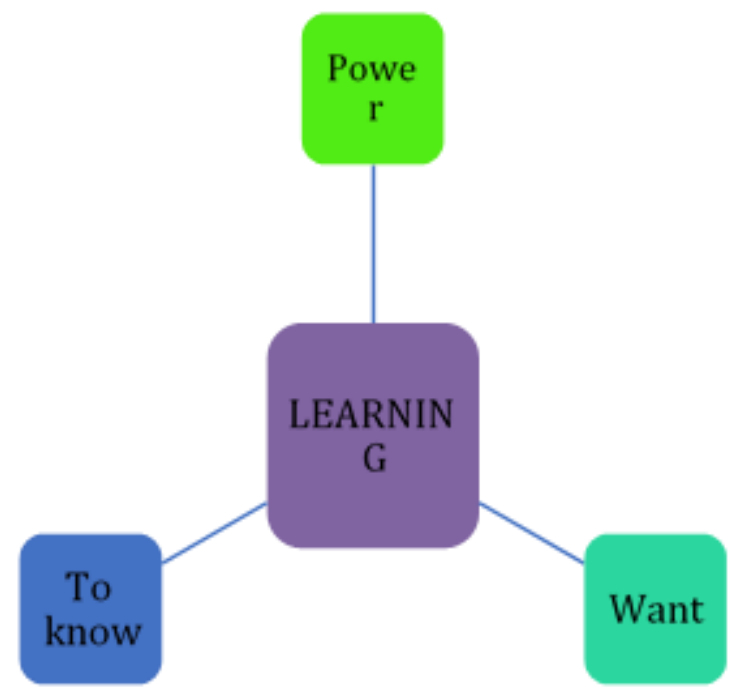

Figure 4. Learning elements

For Carrillo (2009), knowledge, skills, values that students acquire, seal the quality of motivation that constitutes the teacher, psychologist, pedagogues among other specialists related to education, they are mainly those who drive with the performance to unfold by itself in front of its surroundings, labor, social or educational.

\section{Conclusion}

Motivational techniques must be increased in an educational way and with the benefit of student learning so that they generate values and demands in their knowledge, interest in the skills they develop during education. Teachers must provide more positive motivation in the students inside and outside the learning context giving productivity to the educational environment and at the same time strengthening the values in their teaching.

\section{Conflict of interest statement}

The authors declared that they have no competing interests.

\section{Statement of authorship}

The authors have a responsibility for the conception and design of the study. The authors have approved the final article.

\section{Acknowledgments}

The authors would like to thank the editor of IRJMIS for their valuable time, support and advice in completing the current study.

Alcivar, C. M. M., Quimi, T. L. I., \& Barberan, M. F. Z. (2020). The motivation and its importance in the teachinglearning process. International Research Journal of Management, IT and Social Sciences, 7(1), 138-144. 


\section{References}

Alava, E. E., \& Martinez, M. E. M. (2019). Impact of teaching-learning process for brain. International Journal of Health Sciences, 3(1), 33-40. https://doi.org/10.29332/ijhs.v3n1.304

Alvarez-Alemán, A., Austin, J. D., Jacoby, C. A., \& Frazer, T. K. (2018). Cuban connection: regional role for Florida's manatees. Frontiers in Marine Science, 5, 294. https://doi.org/10.3389/fmars.2018.00294

Carrillo, M.P. (2009). Motivation and learning Dialnet., 4(2). Retrieved from https://www.google.com/search?q=MOTIVACION+Y+APRENDIZAJE+DIALNETD.\&oq= MOTIVACION+Y+APRENDIZAJE+DIALNETD.+\&aqs=chrome..69i57j33.19281j1j8\&sourceid=chrome\&ie= UTF-8

Cazorla, K.C. (2015). MOTIVATION FOR LEARNING IN STUDENTS. Thesis.Retrieved from https://dspace.ucuenca.edu.ec/bitstream/123456789/23533/1/tesis.pdf

E. Llanga, J.M. (2019). Motivation as a factor in learning. Eumed.net.Obtained from https://www.eumed.net/rev/atlante/2019/06/motivacion-aprendizaje.html

García, F. (1997). Motivation, learning school performance. DIALNETD, 1(0). Retrieved from https://www.google.com/search?q=MOTIVACION+Y+APRENDIZAJE+DIALNETD.\&oq=MOTIVACION+Y +APRENDIZAJE+DIALNETD.+\&aqs=chrome..69i57j33.19281j1j8\&sourceid=chrome\&ie=UTF-8

J Valenzuela, C.M. (2015). School motivation: Keys to motivational training. Scielo, 41(1). Retrieved from https://scielo.conicyt.cl/pdf/estped/v41n1/art21.pdf

Macías, EIP, Cedeño, HAC, \& Chávez, GMR (2018). Importance of Improving Resilience in Teaching-Learning Process of Students with Disabilities. International Research Journal of Management, IT and Social Sciences, 5 (2), 120-128.

Maggiolini, I. (2013). Motivational strategies in a digital age: Mobile phones and. Dialnet(24). Retrieved from https://www.google.com/search?ei=nOv6XZqDOpC85gKL_J_QCQ\&q=la+motivacion+y+su+impotrtancia+enel +aprendizaje+dialnet.net.\&oq=la+motivacion+y+su+impotrtancia+enel+ learning + dialnet.net. \& gs_l = psyab.3..33i10i16014.6623.21363..21987 ... 2.2..2.1302.7438.2-1j1j

Mero, C.M. (2019). Importance of brain knowing for receiving information. International Journal of Social Sciences, 3(1). Retrieved from https://doi.org/10.31295/ijss.v3n1.100

Moreno, J., \& Rodriguez, I. (2018). The importance of emotion in learning: Proposals to improve student motivation. Dialnet.net, $15(29)$ Retrieved from https://www.google.com/search?ei=nOv6XZqDOpC85gKL_J_QCQ\&q=la+motivacion+y+su+impotrtancia+enel +aprendizaje+dialnet.net.\&oq=la+motivacion+y+su+impotrtancia+enel+ learning + dialnet.net. \& gs_l = psyab.3..33i10i16014.6623.21363..21987 ... 2.2..2.1302.7438.2-1j1j

Morón, M. (2011). THE IMPORTANCE OF MOTIVATION IN EDUCATION. Digital magazine for teaching professionals, $1(12)$ Retrieved from https://www.google.com/search?sxsrf=ACYBGNRUJXjJ5W2dKqx8d9_DI12KmOJf6g:1577733625493\&q=imp ortancia+de+la+motivacion+en+la+educacion\&sa=X\&ved=2ahUKEwizprDii97mAhVNq1kKHaKSCykQ1QIoA noECAwQAw\&biw $=1366 \&$ bih $=657$

Ospina, J. (2006). The motivation, motor of learning. Journal of Health Sciences. Scielo, 4(2). Retrieved from https://www.google.com/search?q=LA+MOTIVACION+Y+SU+IMPORTANCIA+EN+ESTUDIANTES.SCIEL O\&oq=LA+MOTIVACION+Y+SU+IMPORTANCIA+EN+ESTUDIANTES.SCIELO\&aqs=chrome. .69i57.24263j0j7 \& sourceid $=$ chrome \& ie = UTF-8

Revelo-Sánchez, O., Collazos-Ordóñez, C. A., \& Jiménez-Toledo, J. A. (2018). El trabajo colaborativo como estrategia didáctica para la enseñanza/aprendizaje de la programación: una revisión sistemática de literatura. TecnoLógicas, 21(41), 115-134.

Rodríguez, M. (2012). The motivation in the teaching-learning process. EFDeportes.com, Digital Magazine. Buenos Aires (170). Retrieved from https://www.google.com/search

Sotomayor, D.M. (2016). Social networks as motivation for learning: opinion of teenagers. INNOEDUCA, 2(1). Retrieved from https://www.google.com/search?q=MOTIVACION+Y+APRENDIZAJE+SCOPUS. 